\title{
LÍNGUA PORTUGUESA COMO L2 PARA SURDOS: ANÁLISE DOS ELEMENTOS LINGUÍSTICOS E TEXTUAIS EMPREGADOS POR UM ESTUDANTE SURDO BILÍNGUE
}

\author{
PORTUGUESE LANGUAGE AS L2 FOR THE DEAF: ANALYSIS OF THE \\ LINGUISTIC AND TEXTUAL ELEMENTS EMPLOYED BY A BILINGUAL \\ DEAF STUDENT
}

\author{
Carlos Antonio Jacinto ${ }^{1}$ \\ Michelle Nave Valadão ${ }^{2}$ \\ Adriana da Silva ${ }^{3}$
}

\section{Resumo}

Em uma sociedade multiletrada, a aquisição da Língua Portuguesa (LP) escrita, para os surdos, é primordial para a inserção social e para ampliação do universo sóciocomunicativo. Diante disso, buscamos analisar textos de um surdo bilíngue do Ensino Médio, visando identificar a organização linguística, textual e discursiva empregada. Para isso, descrevemos a influência da Libras nas produções em LP e as marcas linguísticas adotadas que ajudaram ou prejudicaram na constituição das produções e, por fim, refletimos como esses aspectos se relacionam no estabelecimento da coesão e da coerência textual. Os resultados demonstraram que o aluno realizou pequenas produções, na sua maioria descritiva, e que em alguns trechos houve rupturas na organização textual que causaram problemas microestruturais, mas não prejudicaram a coerência e o sentido global das produções. Constamos a influência da Libras na estrutura da LP, a qual foi atribuída como produto de uma interlíngua.

\section{Palavras-Chave}

Língua Brasileira de Sinais. Interlíngua. Bilinguismo. Letramento.

\begin{abstract}
In a multiliteracy society, the acquisition of Portuguese Language (LP) writing skill for deaf people is central, in addition, this acquisition is an extension of the socio-communicative universe. Thus, we sought to analyze texts of a bilingual deaf high school, aiming to identify the linguistic, textual and discursive organization employed. For this, we describe the influence of Libras on LP productions and the adopted linguistic marks that helped or hindered the constitution of productions and, finally, we reflect on how these aspects relate in the establishment of cohesion and textual coherence. In the textual productions, the analyzes looked for the identification of the linguistic movements, from textual elements, such as cohesion and coherence. The results showed that the student made small productions, mostly descriptive, and that there were, in some sections, cohesion ruptures, which did not affect the texts coherence. It was verified influence of Libras in the Portuguese Language structure, which was considered as a result of an interlanguage.
\end{abstract}

\section{KeYWORDS}

Brazilian Sign Language. Interlanguage. Bilingualism. Literacy.

1 Mestrando em Linguística Aplicada pela Universidade Federal de Viçosa - UFV.

2 Doutora em Neurologia pela Universidade de São Paulo, Professora do Departamento de Letras da UFV.

3 Doutora em Linguística pela Universidade de Campinas, Professora do Departamento de Letras da UFV 


\section{INTRODUÇão}

A discussão sobre a educação de surdos ganhou grande notoriedade nos últimos anos, e, no cenário nacional, tem despertado preocupações em relação ao ensino da Língua Portuguesa (LP), especialmente, no âmbito das escolas inclusivas. Isso porque, nessas escolas, os professores e professoras precisam lidar com a tarefa de educar estudantes ouvintes e surdos em uma mesma sala de aula, e muitos profissionais não têm formação para levar em consideração as características linguísticas dos surdos, que têm a Língua Brasileira de Sinais (Libras) como primeira língua (L1) e a Língua Portuguesa como segunda língua (L2) na modalidade escrita. No âmbito do componente curricular LP, os docentes que lecionam para surdos lidam com uma condição bilíngue bastante peculiar: em que há estudantes que, geralmente, não têm conhecimentos da modalidade oral na L2 e nem da modalidade escrita na sua L1, já que os sistemas de escrita das línguas de sinais ainda não são amplamente conhecidos pelos surdos, por não serem oficialmente usados nessas escolas ${ }^{4}$.

Diante dessas questões, durante o processo de ensino e aprendizagem da LP, os professores devem ter clareza da condição linguística desses estudantes, a fim de estimular o desenvolvimento de competências na escrita que lhes assegurem a participação nas mais diversas práticas sociais de uso da língua, assim como é defendido por Lodi, Bortolotti e Cavalmoreti (2014) e por Streiechen e Krause-Lemke (2014). Nesse contexto, o ensino e a aprendizagem da LP assume uma concepção voltada ao letramento que, no sentido proposto por Signorini (2001), se constitui em uma prática social, nesse caso, intrinsecamente relacionada ao uso da Libras e permeada de valores sociais, culturais, linguísticos, políticos e ideológicos. Nessa perspectiva bilíngue, as práticas sociais de letramento dos surdos pressupõem a Libras como principal mecanismo de interlocução, sendo a LP escrita uma propulsora da ampliação da capacidade comunicativa e da autonomia na construção de conhecimentos, ao possibilitar a produção e também o acesso aos textos na língua original, sem a necessidade de tradução para a Libras.

Tendo em vista que nas escolas inclusivas a Libras e a LP compartilham o mesmo espaço educacional, são necessários estudos que produzam conhecimentos possíveis de serem aplicados nas práticas docentes de letramento dos surdos, considerando as particularidades envolvidas. Para contribuir com esse propósito, visamos, neste trabalho ${ }^{5}$, analisar a construção da textualidade, tendo como ponto de partida dois dos fatores que a constitui: a coesão e a coerência. Para isso, partimos de uma análise de aspectos linguísticos para uma análise que se preocupa com a construção do sentido baseada em aspectos microestruturais como a coesão para os macroestruturais como a coerência.

\section{A APRendizagem da LP COMO L2 PARA SURdos No CONTEXTO INClusivo}

A aprendizagem de uma segunda língua é uma oportunidade de valor educacional e cultural inestimável. Tratando-se dos surdos, aprender a LP escrita é uma possibilidade de assegurar os seus direitos, enquanto cidadãos, e de adquirir informações e conhecimentos, além de interagir com a

\footnotetext{
4 De acordo com Stumpf (2005), a escrita da língua de sinais pode ser realizada por meio do sistema SignWriting, funcionando de maneira semelhante a "um sistema alfabético, em que as unidades gráficas fundamentais são usadas para representar as unidades gestuais fundamentais, suas propriedades e relações” (p. 51), e que pode ser usado para qualquer língua de sinais. A autora foi pioneira no estudo do SignWriting para o ensino da escrita de língua de sinais e letramento para crianças surdas usuárias da Libras. 5 A pesquisa contou com apoio financeiro do CNPq - edital/2017.
} 
sociedade ouvinte que não possui o domínio da Libras, consequentemente, ampliando o seu universo sociocomunicativo, conforme descrito em Santos (2009).

Por se tratar de uma habilidade complexa e que exige o uso de recursos de forma coesa e adequada, escrever é uma atividade que requer prática e muita dedicação. Para os surdos, as habilidades de compreensão e produção textual são consideradas essenciais no âmbito da aprendizagem da L2, como defendido por Meirelles e Spinillo (2004), que destacam o fato de que pouco se sabe a respeito das produções textuais dos alunos surdos, pois são escassos os estudos voltados para a análise dos textos desses estudantes. Além disso, o referencial teórico disponível não tem esclarecido muitas questões referentes à interferência da Libras na escrita em LP dos surdos.

Em relação à educação inclusiva, a maior problemática do ensino de LP é decorrente do fato de que, nas turmas mistas, não há diferenciação metodológica para o ensino da língua, desconsiderando que os surdos se comunicam por uma língua espaço-visual, diferentemente dos ouvintes, e, portanto, devem aprender a LP escrita como L2.

Sendo assim, como é apontado por Barros, Nascimento e Borges (2017), os alunos ouvintes, ao chegarem à escola, já possuem conhecimentos prévios sobre a LP, enquanto que os surdos, comumente, não os apresentam. Os autores destacam também que "[...] um dos grandes impasses que acontece com os surdos é a falta de um suporte linguístico, pois durante todo o aprendizado os professores farão o trabalho utilizando a escrita em ligação com a fonética" (BARROS; NASCIMENTO; BORGES, 2017, p. 2). Portanto, o ensino da LP para surdos deveria partir das experiências do sujeito surdo com a sua L1, sem se basear na oralidade.

Ao considerarmos essas ponderações, com embasamento em Fernandes (2003), acreditamos que, ao se falar em educação de surdos não se deve utilizar o termo alfabetização, uma vez que esta pressupõe a relação entre letras e sons. Outros autores como Karnopp (2004), Góes e Lopes (2004) reiteram que ao se referir ao ensino e aprendizagem da LP para surdos seja usado o termo letramento, pois, para as autoras, os surdos não serão alfabetizados, já que aprenderão a escrita sem relacionar a grafia com o som, e, sim, letrados, relacionando estruturas e regras por meio das características visuais adquiridas pelo contato constante com os mais diferentes textos escritos nas mais diversas situações sociais.

Mediante a proposta de letramento, o ensino da LP para surdos deve focar em atividades que sejam significativas e contextualizadas, oportunizando aos estudantes o contato com gêneros textuais diversificados (Santos, 2009). Ademais, esse ensino deve partir das experiências e vivências que o aluno já teve na L1, além de considerar que algumas inadequações, comumente observadas na escrita dos surdos, devem ser legitimadas como interferências naturais da Libras na produção dos textos. É importante que o professor compreenda que se trata de línguas distintas com modalidades diferentes. No caso da LP, sabemos que ela contém classes de palavras como artigos, preposições, conjunções, entre outros, que são inexistentes em Libras. Com relação a essas diferenças, Salles et al. (2004, p. 34) descreve que:

há diferenças estruturais entre línguas de sinais e línguas orais e, por isso, as relações entre as estruturas não se estabelecem da mesma forma nos dois sistemas linguísticos. Nesse sentido, uma das dificuldades que o surdo tem apresentado na sua produção textual em português é exatamente a de fazer ligações entre palavras, segmentos, orações, períodos 
e parágrafos, ou seja, a de organizar sequencialmente o pensamento em cadeias coesivas na língua portuguesa.

Por esses motivos, ao analisar as produções textuais dos alunos surdos, os professores precisam saber identificar as interferências da Libras na escrita em LP, a fim de que não considerem os desvios como erros, assim como é defendido por Guarinello (2007, p. 87), quando menciona que os "erros devem ser encarados como decorrentes da aprendizagem de uma segunda língua, ou seja, resultado da interferência da sua primeira língua e da sobreposição das regras da língua que está aprendendo". Tal recomendação também é apontada pelo Decreto no 5626/2005 (BRASIL 2005) ao determinar que as instituições de ensino, na correção das provas escritas, devem "adotar mecanismos de avaliação coerente com o aprendizado de segunda língua, valorizando o aspecto semântico e reconhecendo a singularidade linguística manifestada no aspecto formal da Língua Portuguesa". Nesse entendimento, autores como Lodi, Bortolotti e Cavalmoreti (2014), e Streiechen e Lemke (2014) relatam que ao desconsiderarem as especificidades linguísticas dos surdos na produção dos textos escritos, os professores perdem a oportunidade de usar da função metalinguística para que os estudantes reflitam sobre os sentidos dos textos e construíam hipóteses sobre as línguas. Romper com tal conduta se faz necessário mediante o processo longo e gradativo que transcorre o ensino e a aprendizagem da LP, como alertado por Dechandt (2003):

a apropriação de uma L2 pelos surdos, no caso a escrita do Português, caracteriza-se por um processo contínuo, constituído por etapas que se sucedem no tempo, cujo ponto de partida é a língua de sinais (L1) e o ponto de chegada é a língua portuguesa (L2), na sua modalidade escrita. Cada uma dessas etapas constitui a sua interlíngua (DECHANDT, 2003, p. 312).

Nesse sentido, consideramos que o ensino da LP escrita para os surdos envolve uma atividade gradual e flexível, na qual os aprendizes vivenciam etapas constituídas por uma interlíngua, tendo em vista a conceptualização de Selinker (1972) que trata a interlíngua como um sistema linguístico próprio, baseado na produção do aprendiz, resultado das tentativas de produção na língua-alvo.

Com base nesses apontamentos, consideraremos que as produções do estudante surdo apresentarão formas que podem ser relacionadas com a L1 ou até mesmo formas que não pertencem nem a esta e nem a L2. Nesse sentido, tal definição é pertinente às características que serão abordadas neste artigo, ao considerarmos que o aluno surdo, enquanto aprendiz da LP como L2, também está sujeito a reproduzir características da Libras na sua produção escrita.

\section{A Coesão e CoerênCia em Produções textuais de surdos}

Estudos voltados para investigar as práticas de professores de LP, que atuam com surdos em escolas inclusivas, demonstram que para facilitar a aprendizagem da LP, esses professores apresentam equivocadamente aos alunos surdos aspectos restritos da língua, enfatizando o ensino do vocabulário, além disso quando adotam textos, esses são curtos e descontextualizados, por vezes, adaptados ou simplificados pelos professores (PEREIRA, 2011; VALADÃO; JACINTO, 2017). Nessas práticas, o trabalho com elementos coesivos e de construção textual é uma atividade pouco abordada. Segundo Bastos (1994), nas atividades avaliativas, os professores insistem na correção linguística e gramatical, exigindo ao máximo a presença de marcas de coesão, ainda que tal aspecto 
não tenha sido apropriadamente abordado nas aulas. Contudo, conforme descrito por Charolles (1978) e Koch e Elias (2007), os elementos linguísticos que são adotados na estrutura textual, constituintes da coesão, não são os únicos responsáveis pelo estabelecimento da coerência, pois fatores sociais e cognitivos também interferem no processo de construção e compreensão textual. É importante ressaltar, no entanto, caso haja o encadeamento dos elementos coesivos de forma satisfatória, esses mecanismos podem levar à constituição e podem corroborar no estabelecimento da coerência. Nesse sentido, Koch e Elias (2007) apresentam que a coerência é externa ao texto, cabendo a nós, leitores, em um processo de interação com o texto e o autor, por meio das pistas que nos sãos oferecidos e por meio do nosso conhecimento linguístico e de mundo, constituir a coerência.

No âmbito do ensino da LP e do trabalho com o texto em sala de aula, os pressupostos teóricos desenvolvidos na área da Linguística Textual têm oferecido subsídios de atuação e intervenção para o trabalho com recursos linguísticos, mecanismos textuais e discursivos que são necessários para o desenvolvimento de uma abordagem consciente do texto (Silva, 2018). Diante dessa realidade, o texto é tido como objeto de estudo na Linguística Textual, tendo como principal característica e partícula constitutiva a textualidade. Isto é, para que haja a textualidade um texto deve cumprir sete requisitos básicos, a saber: coesão, coerência, informatividade, intencionalidade, aceitabilidade, situacionalidade e intertextualidade. Para este estudo, apesar de termos como objeto de análise produções textuais, interessa-nos abordar apenas como os elementos presentes na estrutura textual podem levar a constituição da coesão e coerência. Pois, sendo Koch (2014) os PCNs apresentam que a textualidade é dada por meio de um conjunto de relações que têm por base a coesão e a coerência, explicitando a relação existente entre esses dois conceitos.

Em relação à coesão e à coerência, é de amplo conhecimento a importância desses mecanismos ao relacionar os aspectos semânticos e sintáticos na construção de sentido dos textos. De acordo com Fávero (2007), a coesão e a coerência são dois princípios importantes da textualidade. A autora explicita que a coesão se manifesta no nível micro textual, e se refere à forma como os componentes do texto estão ligados em si dentro de uma sequência. Ainda segundo ela, a coerência diz respeito aos modos como "os conceitos e as relações subjacentes ao texto de superfície, se unem numa configuração, de maneira reciprocamente acessível e relevante” (p. 10). Metaforicamente, podemos considerar coesão e coerência como os dois lados de uma moeda e, dessa forma, para considerarmos um texto como coeso e coerente, elementos linguísticos do texto e até mesmo fatores extralinguísticos precisam estar relacionados na estrutura textual, possibilitando, assim a interpretação do mesmo.

Fávero (2007), propondo uma classificação em termos das funções que exercem os mecanismos coesivos, caracteriza a coesão em três tipos: referencial, recorrencial e sequencial. Para ela, a coesão referencial diz respeito aos itens da língua que têm a função de estabelecer referência, ou seja, que sozinhos não podem ser interpretados. Esse tipo de coesão é dividida em substituição e reiteração; a primeira se dá quando algum item é retomado ou precedido por uma pró-forma, no caso da retomada, temos a anáfora; e, na antecipação, a catáfora. Por sua vez, a segunda, acontece quando há a repetição de termos e expressões com o mesmo referente no texto, podendo se dar 
por meio da repetição de um item lexical, sinônimos, hiperônimos e hipônimos, expressões nominais definidas e nomes genéricos.

Ainda para a autora, a coesão recorrencial consiste em manter o fluxo da informação progredindo, apesar de haver retomada de estruturas, itens ou sentenças. É um meio de adicionar informações novas àquelas já conhecidas no texto. Ela pode ocorrer por meio de recorrência de termos, quando há a repetição de um texto objetivando exercer alguma função determinada, como ênfase e intensidade; por meio do paralelismo, quando estruturas são reutilizadas, mas apresentando diferentes conteúdos. Também pode acontecer por meio da paráfrase, que consiste em uma atividade de reformulação, atuando na articulação de ideias novas e outras já mencionadas, mas agora de maneira criativa e autônoma. E, menos frequente, por meio do uso de recursos fonológicos, segmentais e suprassegmentais. Por último, Fávero (2007) expressa que a coesão sequencial também se relaciona à progressão do texto, permitindo caminhar o fluxo informacional, porém se diferencia da recorrencial por não haver a retomada de itens, sentenças ou estruturas. Este tipo de coesão pode ocorrer das seguintes maneiras: sequenciação temporal, quando todo o enunciado expressa as marcas de localização temporal e ordenação relativas; e por conexão das orações, podendo expressar, por exemplo, causa, condição, finalidade, conformidade, explicação, adição e adversão.

Com base nessa breve descrição dos aspectos, consideraremos que as marcas de coesão estão presentes e se expressam no texto, mas a coerência não estará explicitamente no texto, mas só será constituída por meio deste, com base em elementos de ordem semântica, cognitiva, pragmática e interacional (Koch e Elias, 2007). Dessa maneira, a prática de produção textual se constituirá na relação produtor-texto-receptor e envolverá conhecimentos linguísticos, enciclopédicos, cognitivo e interacional (Koch, 2002).

\section{Percurso metodológico}

O trabalho apoiou-se nas premissas de uma pesquisa do tipo analítica descritiva de abordagem qualitativa (Gil, 2011). Quando ao método, constituiu-se em um estudo de caso, pois envolveu "um estudo profundo e exaustivo de um ou de poucos objetivos, de maneira a permitir o seu conhecimento amplo e detalhado" (GIL, 2011, p.57-58). Nosso sujeito de pesquisa foi um estudante surdo bilíngue com 16 anos de idade, que frequentou, em 2016, o $1^{\circ}$ ano do Ensino Médio em uma escola estadual de uma cidade da Zona da Mata mineira. O aluno é filho de ouvintes e foi diagnosticado ainda na infância com perda auditiva congênita neurossensorioneural bilateral profunda, por isso, faz uso de aparelho de amplificação sonora e frequentou sessões de fonoaudiologia, mas não desenvolveu habilidades auditivas e de oralidade. Comunica-se por meio da Libras.

Durante o ano de desenvolvimento da pesquisa, coletamos as produções textuais do estudante surdo, realizadas nas aulas de LP, na referida escola. Para este artigo, selecionamos quatro textos, nos quais foram analisados a coesão e a coerência em LP, a partir da interferência da Libras como L1. Em relação aos critérios utilizados para as análises, buscamos, amparados em Streiechen e Krause-Lemke (2014), analisar as trocas morfológicas, sintáticas e demais ocorrências descritas por esses pesquisadores, não como supostos erros do estudante, mas identificando a relação entre a Libras e a LP. Amparados em Oliveira (2013), selecionamos as nomenclaturas referentes aos movimentos linguísticos e textuais que foram mais recorrentes e os analisamos com base em autores 
que pesquisam a escrita em LP de surdos. As análises apoiaram-se também nos princípios da Linguística Textual, e foram embasadas, principalmente, em Fávero (2007) e Koch (2005).

\section{ANÁlise e discussões dos DAdos}

Objetivando verificar as características que demarcam a prática de escrita do sujeito pesquisado, analisamos os movimentos e recursos linguísticos, textuais e discursivos empregados pelo aprendiz, como também a presença ou a ausência de elementos linguísticos característicos da Libras, tentando chegar a constituição e análise da coesão e coerência textual. Em nossas análises buscamos ver como esses elementos linguísticos, apresentados na superfície textual, podem nos dar pistas da construção mais profunda do texto, do seu sentido, podendo servir de base para que o professor de LP veja o texto do aluno de forma mais ampla.

Nos quadros a seguir, estão representadas as transcrições digitadas dos textos produzidos pelo estudante, sendo enumeradas as linhas. Importa mencionar que os textos originais não foram apresentados por motivos éticos, a fim de evitar a identificação do estudante por meio do reconhecimento da sua letra. O quadro 1 refere-se à produção I, intitulada "Jogos Olímpicos-Olimpíadas Rio 2016"; o quadro 2 diz respeito à Produção II, intitulada "Morte"; o quadro 3 trata da produção III, intitulada "O consumista"; e o quadro 4 expõe a produção IV, sem título.

Quadro 1 - Produção I, intitulada “Jogos Olímpicos-Olimpíadas Rio 2016

1 - Jogos Olimpicos-Olimpiadas Rio 2016

2 - O esporte muito importante porque

3 - ajuda saúde. Também o esporte ajuda a

4 - desenvolver a mente.

5 - Nós tornamos pessoas melhores

6 - Eu gosto de ver o o futibol.

7 - Também eu gosto de todos jogos

8 - porque é muito divertido.

9 - Ver Na televisão eu fico animado

10 - Queria ir no Rio ver jogos.

Fonte: Dados da pesquisa.

Quadro 2 - Produção II, intitulada "Morte"

1 - Morte

2 - Na morte as pessoas sentem feliz,

3 - porque alivio da dor, sofrimento.

4 - Hoje no mundo muito problemas.

5 - Exemplo: desastre natural, peixes morrendo

6 - porque as águas estão sujas, também as pessoas

7 - morrendo perdendo suas casas.

8 - Também vemos violência, Bombas, guerras.

9 - Crianças perdendo seus pais, muitos sofrimento.

10 - Na família porque ficam divididas, perdem

11 - seus pais fican sozinha, muito dificil.

12 - Hoje também as vezes vontade passar, mas muito

13 - perigoso nas cidades.

Fonte: Dados da pesquisa. 
Quadro 3 - Produção III, intitulada "O consumista"

1 - O consumista

2 - Hoje pessoas querem comprar celulares.

3 - Depois elas veem na televisao celulares novos

4 - e querem comprar. Seu cartão de crédito está

5 - sem limite, mas mesmo assim as pessoas

6 - querem comprar novos celulares, porque pensa

7 - so em celular comprar.

8 - Esse comportamento traz muitas doenças,

9 - porque as pessoas ficam com muitos

10 - dividas e com isso a saúde perde.

11 - Também muito estres, porque não con

12 - segue pagar as dívidas.

13 - O melhor é pensar antes de comprar.

14 - As pessoas precisa ter consciência.

Fonte: Dados da pesquisa.

Quadro 4 - Produção IV, sem título

1 - Hoje as pessoas não comunicam porque só pensa

2 - em celular, passar mensagens para amigos, famílias etc...

3 - Então vemos muita falta de comunicação entre as pessoas.

4 - Elas não se falam pessoalmente, só por celular e

5 - causa muitos problemas. Por exemplo: sentem sem

6 - amigos de verdade, porque não tem comunicação pessoal

7 - só virtual.

8 - Também entre amigos juntos saem para passear,

9 - a pessoas isola para conversar no celular

10 - Por isso, a era da solidão acompanhada, pessoa

11 - só com o celular. A foto mostrou isso, o homem

12 - mensagens no celular, isolado

13 - A outra foto também mostrou a mulher no

14 - restaurante no celular, não socializando.

Fonte: Dados da pesquisa.

Assim como enfatizado anteriormente, nossas análises terão como base três eixos: descrever o uso adequado ou inadequado de marcas linguísticas relacionadas aos aspectos mais formais da LP, tais como uso de acentuação, pontuação e concordância; analisar a influência da Libras nas produções em L2, considerando elementos que são inexistentes ou que apresentam usos diferentes em Libras e LP; apresentar os elementos ligados à coesão, ou seja, aqueles presentes na estrutura e utilizados na organização textual, que foram adotados pelo aluno. E, finalmente, refletiremos como esses usos supracitados acima contribuem ou não para a constituição do sentido textual, isto é, apontar se o uso ou ausência dessas formas linguísticas foram benéficas ou prejudiciais para a concepção da coerência.

Dedicando-nos primeiramente ao primeiro eixo analítico, as análises das produções demonstraram que, em relação aos Movimentos Linguísticos relativos aos aspectos formais da língua LP, ou seja, elementos que são oriundos de estudos e formas gramaticais, que selecionadas e combina- 
das, "dentro das inúmeras possibilidades que a gramática da língua nos põe à disposição, nos textos que lemos ou produzimos, constitui um conjunto de decisões que vão funcionar como instruções ou sinalizações a orientar a busca pelo sentido" (KOCH, 2002, p. 3). Assim sendo, observamos que nas produções ocorreram os seguintes desvios gramaticais e sintáticos: acentuação gráfica não marcada; ausência de termos sintáticos; modificação na estrutura segmental da palavra; concordância. Verificamos que esses desvios chegam a comprometer a produção textual do aluno pontualmente, microestruturalmente, mas não o sentido total do texto, a macroestrutura.

Sobre a acentuação gráfica não marcada, observou-se que na produção I o aluno não acentuou, na linha 1, as palavras "olímpicos" e "olimpíadas". Já na linha 5, o uso indevido do acento gráfico provocou a mudança do tipo de pronome pessoal, pois o aluno fez o uso do pronome reto "nós", enquanto a frase pedia um oblíquo "nos", prejudicando a coesão. Sobre isso, Silva (2013) argumenta que a concepção de pronomes retos e oblíquos é inexistente na Libras. De acordo com Felipe (2007), os pronomes na Libras se dão por meio da apontação de referenciais, que podem estar presentes fisicamente ou podem ser colocados virtualmente no espaço de sinalização. Diante disso, não há um sinal específico para representar os pronomes da LP. Na produção II, destacou-se a ausência de acentuação nas palavras "alívio", "difícil" e "às", respectivamente, nas linhas 3, 11 e 12. Por sua vez, na produção III, observou-se, nas linhas 3, 7 e 10, respectivamente, a ausência de acentuação nos termos "televisão", "só" e "difícil". Notou-se que na produção IV, todas as palavras foram acentuadas corretamente. De maneira semelhante aos nossos achados, ao analisar os textos escritos de estudantes surdos, Guarinello (2007) observou que eles não utilizavam acentuação nas palavras que escreviam. Também, Fernandes (2007) e Pereira (2010) destacam que pelo fato de na LP a acentuação gráfica ser um fator relacionado à intensidade e à tonicidade, é comum observar a ausência de tal marca nas produções de surdos. Do mesmo modo, Streiechen e Krause-Lemke (2014) argumentam que, por não pronunciarem as palavras, é recorrente que os surdos apresentem dificuldades na acentuação. Nesse sentido, Pereira (2010, s/p) também enfatiza que:

[...] é muito complicado trabalhar pela visão a sílaba tônica de uma palavra. A língua de sinais não tem acento. Os surdos acabam aprendendo a acentuar as palavras pelo visual, pelo desenho da palavra e não, obviamente, pela sonoridade. Mas aprendem. Principalmente, os que leem muito. (PEREIRA, 2010, s/p).

Desse modo, pode-se afirmar que a falta de acentuação na produção escrita de surdos é esperada, sendo necessário que os professores busquem estratégias de ensino da acentuação de modo diferenciado, uma vez que não é possível basear-se nos mesmos métodos adotados para os alunos ouvintes, com ênfase na sonoridade.

No que se refere à segunda categoria de análise, ausência de termos sintáticos, foi possível observar a ausência do verbo "ser" conjugado na terceira pessoa do singular na produção I, linha 2 , na passagem "o esporte muito importante porque". A omissão do verbo pode se justificar pelo fato de a comunicação em Libras, comumente, não usar sinais para representar os verbos de ligação, como observado por Fernandes (2007). Por sua vez, Brito (1995) explica que na Libras não existe uma forma correspondente ao verbo "ser" da LP, sendo assim, esse verbo é usado como empréstimo da LP, o que justificaria tal omissão. Já na produção II, averiguou-se, nas linhas 3 e 4, a ausência do verbo "ter/haver" conjugado na terceira pessoa do singular. O aluno escreveu da 
mesma forma que sinaliza, omitindo o verbo e o artigo. Como se sabe, em Libras, o verbo "ter" é utilizado com mais recorrência para indicar possessão e, na maioria dos casos, a sua omissão não prejudica o sentido, conforme apontado por Quadros e Karnopp (2004).

Com relação à terceira categoria de análise, destacou-se na produção I, na linha 6, a frase "eu gosto de ver o o futibol". Nesse exemplo, ao se referir à palavra "futebol", o aluno modificou-a escrevendo-a com “i”, no caso "futibol”. Aparentemente, essa troca poderia estar relacionada a uma interferência da oralidade na escrita, já que a pronúncia da palavra ocorre com o fonema /i/. Entretanto, durante nossas observações, constatamos que o estudante, apesar de não oralizar, realizava leitura orofacial, o que pode ter ocasionado tal manifestação. Outra hipótese pode ser baseada na explanação de Streiechen e Krause-Lemke (2014), quando argumentam que se o surdo nunca teve contato visual com alguma palavra, ou a visualizou poucas vezes, possivelmente, não se lembrará da grafia correta da palavra. Em relação a isso, Fernandes (2007, p. 11) explica que o fato de "O sujeito surdo memorizar as palavras na globalidade, acarreta trocas nas posições ou omissões de letras". No entanto, como se sabe, caso o surdo tenha contato com a palavra e a use em situações cotidianas, a modificação na estrutura da palavra passa a não ser recorrente, visto que a percepção visual é o melhor caminho para o ensino da grafia. Dessa maneira, destaca-se a importância de o surdo está em contato com textos de temáticas variadas, de modo a lhe possibilitar uma ampliação lexical. Tal afirmação vai ao encontro dos argumentos de Pereira (2011), ao defender que esse tipo de atividade é enriquecedora aos surdos, pois, além de possibilitar a leitura, amplia também o conhecimento lexical.

Já na produção II, linha 11, percebemos que o aluno escreveu "fican" no lugar de "ficam". Esse desvio também pode ser decorrente da pouca exposição à forma escrita dessa palavra e mesmo ocorreu na linha 12, na qual o aluno usou o verbo "passar" no sentido de "passear", sendo a hipótese de que isso pode ter sido motivado pela grafia semelhante de tais verbos, que também ocasionou uma incoerência interna na produção. Do mesmo modo, na linha 13, o aluno usou o adjetivo "perigoso" no lugar do substantivo "perigo". Sobre esse aspecto, é importante mencionar que uma característica muito usual na Libras é a de que, em alguns casos, o mesmo sinal pode ser usado para indicar classes de palavras diferentes. Por exemplo, ao sinalizar "natação" e "nadar", o sinal seria o mesmo (BRITO, 1995, p. 64), com relação as palavras "perigoso" e "perigo", a situação é semelhante.

Em relação à ausência de concordância verbal e nominal, notou-se, na produção I, linha 8, que, ao se referir a "jogos", a concordância verbal foi comprometida. Esperava-se que o verbo "ser" estivesse conjugado na terceira pessoa do plural, para concordar com "jogos". Além disso, o termo "divertido" também deveria estar no plural, uma vez que também se refere à "jogos". Na segunda produção, na linha 1 , houve a ausência de concordância de número com relação ao adjetivo "feliz". Na produção 3, observou-se, na linha 6, a ausência de concordância verbal entre os termos "pessoas" e "pensar". O mesmo pode ser notado no final da referida produção, na linha 14, quando o aluno não fez a concordância entre o sujeito "pessoas" e o verbo "precisar". Podemos notar que tal fenômeno também ocorreu na linha 1 da produção 4 , na qual houve a falta de concordância entre o sujeito "pessoas" e o verbo "pensar". No que se refere à concordância de gênero, constatou-se, na produção III, nas linhas 9 e 10, que o aluno usou a palavra "muitos" referindo-se 
à palavra "dívidas". No entanto, ele colocou os dois termos no plural. Sobre esses aspectos, Fernandes (2007), Guarinello (2007) e Streiechen e Krause-Lemke (2014) enfatizam que a ausência de desinência de número e gênero em Libras é uma marca evidente da interferência dessa língua na escrita em L2, assim como as concordâncias inadequadas. De acordo com Silva (2013), devido a influência da Libras, nem sempre os surdos conseguem fazer a concordância de gênero de acordo com as normas da LP. A autora destaca que tal concordância não é uma tarefa fácil de ser realizada, sendo possível observar essas dificuldades também em textos de aprendizes da LP como língua estrangeira, e até mesmo de língua materna.

Após a finalização dessa primeira análise, constatamos que, por serem aspectos pertencentes à estruturação e organização da forma textual, esses aspectos podem sim levar, de certa foram, ao estranhamento pelo leitor em determinadas partes do texto. Nesse sentido, percebe-se rupturas na estrutura textual que podem prejudicar a leitura fluida, o que de certo modo, pode também prejudicar a construção do sentido global do texto, uma vez que todos esses desvios estão relacionados à organização interna das produções. Mas como não são os únicos elementos linguísticos e textuais não são os únicos responsáveis pelo estabelecimento da textualidade, eles podem ser reelaborados pelo leitor de forma a construir o sentido do texto, apesar dos percalços.

No mais, observa-se também que grande parte dessas incoerências são recorrentes da não existência desses aspectos na Libras. Dessa forma, caso o professor utilize metodologias e estratégias de ensino de L2, será possível que o aluno perceba que tais usos ocorrem de outra forma na sua L1 e que, por se tratar de uma L2 na sua modalidade escrita, algumas regras e usos precisam ser transpostas para o papel, diferentemente da sua L1.

Ao compararmos as produções, também categorizamos os elementos que o aluno usou na escrita e que são inexistentes na Libras ou que funcionam de uma outra maneira. Observamos a recorrência de: intensificadores, ordem sintática, conjugação verbal e presença de artigos. Destaca-se que esses elementos aparecem na superfície textual podem ser primordiais para o estabelecimento da ligação interna entre os constituintes linguísticos do texto. Esses elementos são responsáveis pelo processo de referenciarão no texto, mas quando pequenas incoerências ocorrem, não significa que o texto é incoerente, pois outros elementos textuais estão em jogo. Tendo conhecimento que esses elementos são mais difíceis para o aluno surdo, o professor pode se dedicar a tentar compreender essa dificuldade e pensar em mecanismos de ajudar o aluno na produção de LP.

Na produção I, notou-se que o estudante fez uso do advérbio "muito", como observado na linha 2. O uso desse advérbio foi uma característica bastante positiva, pois, na Libras, ele não seria sinalizado, mas incorporado através das expressões faciais e corporais ou por meio da intensificação do próprio verbo. Conforme apresentado por Duarte e Padilha (2012), em uma sentença como "gostar muito", os usuários de Língua de Sinais dificilmente usam o sinal referente à palavra "muito", mas intensificam o verbo por meio de expressão facial, movimento e velocidade. Nesse sentido, encontrar o uso do advérbio "muito" na produção do estudante surdo demarcou uma internalização das normas da LP escrita. Sobre esse aspecto, os referidos autores também enfatizam que na aprendizagem da LP, os surdos precisam "transpor estas ricas informações estruturais da LS para o papel, sem 'distorcer' as estruturas da LP. E vice-versa, pensar na representatividade da 
modalidade escrita de LP com diferentes elementos não existentes em LS" (DUARTE; PADILHA, 2012, p. 319), mostrando que escrever em LP não é uma tarefa simples.

Uma outra categoria importante em nossa análise foi a ordem sintática empregada. Observa-se que, na produção I, o aluno escreve na ordem Sujeito-Verbo-Objeto, como podemos observar em "Eu gosto de ver o o futibol", linha 6, sendo essa a estrutura mais utilizada na LP, apesar da existência de outras. Já na produção III, o aluno opta por usar o objeto antes do verbo, que consiste em uma estrutura comumente usada na Libras. O mesmo ocorre nas linhas 7 e 10, em que podemos perceber os objetos "celular" e "saúde" colocados antes do verbo. Sobre a ordem da frase na Libras, Quadros e Karnopp (2004) argumentam que, apesar de existir muitas possibilidades, parece haver uma preferência pela ordem Objeto-Sujeito-Verbo. Em sua tese de doutorado, Guarinello (2007) também enfatiza que os professores de LP devem se atentar à organização sintática da frase usada pelo aluno surdo, já que a ordem comumente empregada na LP e na Libras são distintas. A autora destaca a necessidade de conscientizar os alunos surdos sobre essas características, salientando as peculiaridades entre as línguas.

Percebemos também que, ao longo das produções, o aluno fez uso de verbos conjugados em pessoas e modos variados, na sua maioria, empregados corretamente. Conforme apresentado por Streiechen e Krause-Lemke (2014), é raro encontrar na escrita de surdos o uso de verbos conjugados segundo a norma culta, pois os surdos escrevem geralmente no infinitivo, já que na Libras a flexão dos verbos não segue o padrão de flexão da LP. Nessa segunda produção, verificamos que o aluno fez uso de tempos verbais variados, tais como presente do indicativo e gerúndio. No entanto, em algumas passagens, ainda há a ausência de verbos ou o uso inadequado. Na produção III e IV fica evidente que o aluno usou verbos no presente do indicativo e todos conjugados. Ao utilizar verbos no mesmo tempo e modo verbal, o estudante possibilitou que a coesão sequencial ocorresse. Ainda sobre a conjugação verbal por surdos, Streiechen e Krause-Lemke (2014) descrevem que, nas práticas escolares, normalmente, os alunos surdos não são levados a comparar as diferenças de flexões verbais que ocorrem entre as línguas orais e as de sinais, o que dificulta a compreensão, por exemplo, de que na LP os verbos passam por modificações de acordo com o tempo da oração. Em consequência dessa postura, muitos surdos somente fazem uso de verbos no infinitivo ou os conjugam no presente e, caso haja usos inadequados de conjugação verbal a coerência pode ser prejudicada, mas não inviabilizada, uma vez que há gêneros e tipos textuais onde certas conjugações e tempos verbais são mais recorrentes.

Conforme apontado por Duarte e Padilha (2012, p. 318, grifo dos autores), destaca que "o surdo precisa 'ver' para aprender a reconhecer e incorporar a estrutura verbal em sua materialização linguística”. Desse modo, destaca-se o papel que um intermediador deve ocupar na construção de escrita, especialmente o professor de LP, sendo necessário que os surdos sejam expostos a esses usos, para que os reconheçam e os adotem na sua escrita.

No que se refere ao uso de artigos, constatou-se que, na produção I, na linha 6, possivelmente por falta de atenção, o aluno duplicou o artigo "o". Apesar de, na maioria dos casos, o aluno fazer uso de artigos corretamente, observa-se que na linha 7 houve a sua supressão, ou seja, o estudante não marcou o artigo "os" antes do termo “jogos". Na produção II, não se observou a omissão. Já na produção III, notou-se, na linha 2, no fragmento "hoje pessoas querem comprar 
celular", que o aluno não utilizou o artigo antes da palavra "pessoas". Nessa produção, essa foi a única passagem na qual o artigo não foi empregado. Na produção IV, na linha 9 , observou-se o uso do artigo "a" no singular, porém o termo "pessoa" estava no plural, rompendo a concordância de número e afetando, dessa forma, a coesão. A presença de artigos no decorrer das produções foi um aspecto positivo, já que na Libras não existem. Ademias, percebe-se uma ruptura local que não rompe com o sentido, pois esse tipo de ocorrência linguística é comum também em produções de falantes da LP como L1. Além disso, vale ressaltar que segundo Guarinello (2007), a utilização aleatória ou inadequada desse elemento pode decorrente de sua inexistência nas línguas de sinais. Dessa forma, por não existir em sua L1, é compreensível que o aluno não tenha se atentado, em alguns casos, para o seu uso.

Em vista do comentado anteriormente, as noções de verbo e estrutura sintática são elementos que atuam, muitas vezes, como ligação entre termos e também permitem uma maior fluidez das informações na estrutura textual. Dessa forma, podemos dizer que eles também são responsáveis pela manutenção da coesão textual em sentido micro e também macro, na construção do sentido do texto. Conforme discutido no decorrer deste estudo, o nosso colaborador de pesquisa se trata de um aprendiz de L2 e que apresenta uma L1 com modalidade distinta da língua que ele está em processo de aprendizagem. Assim, o uso, consciente ou não, desses elementos é uma marca de que o aluno está se aprimorando dessas regras e possivelmente evoluirá cada vez mais no seu nível de interlíngua, acercando-se cada vez mais da forma usual escrita da L2.

Sobre os recursos relacionados à estruturação textual, ao produzir seu texto, o aluno fez uso de mecanismos como: repetição do mesmo item lexical; uso de conectivos; pontuação gráfica. Esses elementos estão diretamente ligados à coesão referencial, sequencial e recorrencial, visando a assimilação das relações semânticas e discursivas entre os elementos constituintes da esfera textual, corroborando para a elaboração da referenciação e progressão textual, importantes elementos na construção do sentido e buscando a construção e reconstrução de objeto-de-discurso (Koch e Elias, 2007). Cabe retomar a discussão trazida na constituição teórica deste estudo que enfatiza que, em termos de coesão e coerência, o uso explicito dessas marcas de coesão não levam necessariamente a coerência, mas contribuem com a sua constituição. Nesse sentido, a adoção de formas de introduzir uma nova entidade ou um referente no texto, assim como a retomada desses elementos por meio de várias estratégias linguísticas e discursivas, leva à constituição da referenciação e da progressão textual, sendo classificadas como estratégias linguísticas e discursivas que estão ligadas à coesão e que podem influenciar na orientação argumentativa e, consequentemente, estabelecer e contribuir com a construção do sentido (Koch e Elias, 2007).

Com relação a esses mecanismos, na produção I o aluno fez uso da repetição do mesmo item lexical "esporte" para manter a temática e a progressão do texto, isto é, usou a coesão referencial por reiteração ao repetir o mesmo item. A repetição do item lexical é, segundo Koch (2005), uma estratégia recorrente na fase inicial de escrita, quando as crianças não sabem muito bem quais estratégias usar. Entretanto, apesar de as frases dessa produção não serem conectadas por mecanismo de coesão, percebe-se que, por se manter a progressão temática, observou-se que a coerência do texto não foi prejudicada, possibilitando que leitor fosse capaz de atribuir sentido no momento da leitura. Outro ponto importante foi que o estudante se apropriou de procedimentos de progressão 
de tópico, mantendo, ao longo da produção, a progressão temática. Todavia, caso o aluno fizesse uso de outros aspectos da coesão referencial, como sinônimos e pronomes, esses aspectos forneceriam maior fluidez ao texto.

$\mathrm{Na}$ produção II, com relação aos fatores relacionados à coesão, o aluno fez uso de conectivos para que seu texto fosse bem estruturado, usando "porque" e "mas" como articuladores textuais. Nesse sentido, percebemos também que nas linhas 4 e 5 o aluno fez uso de catáfora para exemplificar o tema que estava retratando. $\mathrm{Na}$ organização textual da produção III, o sujeito também fez uso de elementos de coesão por meio da utilização dos conectivos "mas", "porque" e "e". Dessa maneira, notou-se a conexão por meio de articuladores textuais. Cabe aqui ressaltar que o uso adequado desses conectivos, além de permitirem a construção da coesão, colaboram para a constituição da coerência, pois tratam-se de operadores que estabelecem as relações lógico-semântico entre as estruturas textuais e o uso de um conectivo de oposição, como "contudo", no lugar de uma relação de adição, como "e", ou explicação, "pois", pode trazer problemas de sentido para a produção, afetando, nesse sentido, a coerência.

Além dos mecanismos linguísticos descritos acima, o estudante também empregou em sua produção a coesão referencial, pois, na linha 8 , o estudante utilizou a pró-forma pronominal "esse" como mecanismo de retomada. Isso ficou evidenciado quando ele fez uso da expressão "esse comportamento" como mecanismo de retomada textual, ou seja, por meio dessa expressão retomou informações citadas anteriormente. Assim, diferentemente da produção I, na qual o aluno somente fez uso da repetição de item lexical, aqui ele usou pronomes que ajudaram na referenciação textual. Esse recurso de referenciação anafórica possibilita que o tema central descrito seja retomado, podendo fazer a ligação com outros assuntos e possibilita a compreensão e manutenção do entendimento do texto em seu sentido global, envolvendo habilidades linguísticas e de conhecimento de mundo do aprendiz de L2. Nesse sentido, quanto mais proficiente o aluno for, mais variado serão os aspectos de retomada lexical.

Já na produção IV, percebemos o uso de elementos coesivos, como dos conectivos "porque" e "por isso". Notou-se a conexão por meio de articuladores textuais. Um outro ponto primordial na análise das produções textuais foi relativo ao emprego da pontuação, sendo essa considerada fundamental para a ligação das partes de um texto. Constatamos que o aluno, no decorrer da produção I, fez uso apenas de ponto final. Sobre o uso da pontuação na LP, essa depende muitas vezes da tonicidade e da entonação da língua, e, como os surdos não pronunciam/vocalizam as palavras e as frases, a ausência ou o uso inadequado é usual em suas produções. Segundo Fernandes (2007) e Quadros e Karnopp (2004), na Libras, a entonação é realizada por meio da expressão facial e, dessa forma, a relação entre Libras e LP torna-se mais difícil para o aluno, uma vez que a transcrição de tal fenômeno para a escrita da L2 passa pela compreensão das características visuais da L1. Na produção II, o aluno empregou ponto final, vírgula e dois pontos, todos utilizados corretamente. Na produção III, o aluno usa a pontuação correta, apesar de somente utilizar ponto final e vírgula, podendo o professor fazer um trabalho intervencionista e mostrar para os alunos como os elementos de conexão são importantes em LP, diferenciando as produções e incentivando o seu uso. Já na produção IV, o aluno utiliza dois pontos, ponto final e vírgula. Contudo, por mais que o aluno usasse uma pontuação variada, nessa produção, observou-se que o emprego da vírgula não 
foi realizado corretamente em todos os casos, podendo o professor realizar um trabalho focado no estabelecimento da coesão por meio de mecanismo de pontuação. Importa mencionar que a ausência da vírgula é uma problemática encontrada com recorrência também em produções de ouvintes que tem a LP como L1, destacando a complexidade do uso na produção. E, além disso, a pontuação pode ser trocada por outros mecanismos de conexão mais adequados.

Dessa forma, percebeu-se que o aluno surdo, enquanto produtor de uma L2, que tem como L1 uma língua de modalidade visual-espacial, conseguiu articular os elementos linguísticos e discursivos de seu texto e parece ter apresentado consciência de aspectos pertencentes à norma culta no processo de escrita da LP.

Com relação ao estabelecimento da coerência, consideramos que ela se dá pela união de fatores como o uso de elementos linguísticos, fatores de ordem cognitiva, situacional, sociocultural, interacional, entre outros (Kock, 2014). Em vista disso, como o nosso objetivo era analisar os elementos estritamente relacionados à estrutura linguística, podemos concluir que, por meio das nossas análises, o uso desses elementos pelo aprendiz surdos pode ter contribuído no estabelecimento da coerência por parte do leitor e, conforme foi demonstrado nas análises, o não uso ou o uso equivocado de alguns aspectos, em pequenos momentos, dificultou a leitura e pode ter exigido dos leitores outras estratégias e recursos interpretativos que não o linguístico. Por consequência, podemos pensar na necessidade de um trabalho que visasse a melhora dessas produções textuais com base nos elementos aqui descritos, de modo a contribuir para uma maior fluidez das produções, tanto no nível micro como no macroestrutural.

Destaca-se também a necessidade de que se considere o contexto de produção, considerando que um texto envolve produtor e receptor com alguma finalidade de interação que é real. Em virtude disso, o estabelecimento da coerência não dependerá somente da organização da estrutura interna do texto, mas se constituirá na ligação entre os objetos do discurso empregados no texto, que são retomados e resignificados por meio da referenciação, utilizando-se de conhecimentos provenientes do autor, explicitados no texto, e também de algumas compreensões por parte do leitor. Nesse sentido, esse novo modo de olhar o texto vai envolver uma relação de construção de sentido que se dará por meio do texto, mas que envolverá elementos enciclopédicos, lexicais, culturais que surgirão na interação entre autor-texto-leitor (Koch, 2009) e levarão a continuidade textual e a produção de sentido.

Por fim, o trabalho em sala de aula de língua, tanto em L1 quanto em L2, deve envolver práticas que insiram o texto no seu contexto real de produção e uso, de modo que produtores e leitores não somente vejam o contexto como uma atividade avaliativa que deva ser cumprida, mas considerem que o texto é a nossa manifestação comunicativa e que, cada uma dessas manifestações se encontra dentro de um contexto e que possuem especificidades que estarão atreladas a ele (Koch, 2009), essa sim deve ser a contribuição essencial da Linguística Textual para o trabalho com o texto em sala de aula.

\section{CONSIDERAÇões Finais}

Nossas observações apontaram que as produções realizadas pelo aluno apresentaram características linguísticas oriundas da interferência da Libras, as quais incidiram na estrutura escrita da LP. No entanto, também foi possível verificar, pelas análises das produções, que o aluno pode ter 
desenvolvido uma escrita consciente em LP, assim como demostrado na assimilação e conhecimentos referentes às normas gramaticais da L2. Além disso, percebemos que, apesar de em alguns momentos a coesão local/interna ser afetada por essas transferências linguísticas, é possível atribuir sentido aos textos do estudante.

As análises foram pautadas em questões ligadas à constituição textual, ao encadeamento desses aspectos e ao uso de elementos que levassem à progressão textual, fatores esses que foram relevantes ou prejudiciais à compreensão da produção textual do sujeito surdo. Assim, as análises demonstraram que apesar de algumas dificuldades nos aspectos de coesão, ou seja, elementos ligados à constituição estrutural do textual, o aluno deu conta de estabelecer o encadeamento dessas formas e assegurou que as produções fossem compreendidas. Verificamos que esses desvios chegaram a comprometer a produção textual do aluno pontualmente, microestruturalmente, mas não o sentido total do texto, a macroestrutura, uma vez que os elementos micrestruturais não são os únicos responsáveis pela construção total do sentido textual, pois outros elementos como os conhecimentos de mundo, entre outros, ajudam no estabelecimento da coerência.

Ademais, devemos considerar também que, fato é que esses aspectos podem ser melhores ou mais bem trabalhados se o professor, tendo consciência das especificidades linguísticas e dos mecanismos de coesão e coerência normalmente usados em LP, poderá facilmente rever essa situação que levam à produção da coerência textual. Além disso, as práticas escolares de produção textual devem ter por base que o estabelecimento da coerência não se restringe ao texto e que, no momento da solicitação das produções textuais os professores devem dar orientações claras e considerar o contexto de produção, uma vez que produzir texto é uma relação que envolve autor, interlocutor e contexto de produção.

Frente ao que foi mencionado, podemos concluir que após várias práticas de escrita, o aluno fez uso de regras linguísticas e estruturais pertencentes à LP, o que pode indicar uma assimilação entre os aspectos que são empregados nessa L2. Tais resultados demostram que é necessário que os surdos sejam expostos cada vez mais à prática de escrita e leitura, para que possam desenvolver-se proficientemente em LP e em contextos diversos. Desse modo, destacamos a importância de os professores que trabalham com ensino de LP em contexto de L2 para surdos, especialmente em ambientes inclusivos, conheçam as especificidades linguísticas e culturais desses estudantes. Enfatizamos ainda ser primordial aos professores o entendimento básico da estrutura gramatical da Libras, para que possam avaliar as produções na qualidade de L2, além de dar orientações que sistematizem os recursos que compõem e estão atrelados à produção e recepção textual.

Por fim, destacamos a necessidade de estudos que investiguem a relação existente entre LP e Libras nas práticas de ensino promovidas junto aos surdos no âmbito das escolas inclusivas, assim como o papel ocupado por ambas as línguas nesses espaços. Como sabemos, tal temática ainda é incipiente no país e, por isso, esperamos que nossas discussões possam contribuir para os estudos de ensino e aprendizagem de LP como L2 para surdos e, especificamente, sobre a formação de professores diante das questões metodológica e das especificidades linguísticas e culturais dos educandos surdos.

\section{REFERÊNCIAS}

ANTUNES, I. Análise de textos: fundamentos e práticas. Parábola, 2010. 
BARROS, A. L. E. C.; NASCIMENTO, J. P.; BORGES, J. P. O.; Aquisição da Língua Portuguesa pelo surdo. Interletras, v. 06, n. 25, p. 1-10, 2017.

BASTOS, L. K. Coesão e coerência em narrativas escolares. Martins Fontes, 1994.

BRASIL. Decreto n. 5.626 de 22 de dezembro de 2005, que regulamenta a Lei n. 10.436, de 24 de abril de 2002, que dispõe sobre a Língua Brasileira de Sinais - Libras, e o Art. 18 da Lei n. 10.098, de 19 de dezembro de 2000. Publicado no Diário Oficial da União em 22 de dezembro de 2005.

BRITO, L. F. Por uma gramática de língua de sinais. Rio de Janeiro: Tempo Brasileiro, 1995.

CHAROLLES, M. Introduction aux problemes de la coherence des textes:(Approche théorique et étude des pratiques pédagogiques). Langue française, 1978, p. 7-41.

DECHANDT, S. B. A apropriação da escrita por crianças surdas. In: QUADROS, R. M. (Org). Estudos Surdos I. Rio de Janeiro: Arara Azul, 2003, p. 284-322.

DUARTE, A. S.; PADILHA, S. de J. Relações entre língua de sinais e língua portuguesa em materiais didáticos: a notação pelos números semânticos. ReVEL, v. 10, n. 19, 2012, p. 309-326.

FÁVERO, L. L. Coesão e coerência textuais. 11 ed., 2. impr.; ed. rev. e atual. São Paulo: Ática, 2007.

FELIPE, T. A. Os processos de formação de palavras em LIBRAS. Educação temática digital, v. 8, n. 2, 2007.

FERNANDES, S. Educação bilíngue para surdos: identidades, diferenças, contradição e mistérios. Curitiba, 2003. Tese (Doutorado em Letras) - Universidade Federal do Paraná.

. Avaliação em Língua portuguesa para alunos surdos: algumas considerações. Curitiba, SEED/ SUED/DEE, 2007.

GIL, A. C. Métodos e técnicas de pesquisa social. 6. ed., São Paulo: Atlas, 2011.

GÓES, M. C. R.; LOPES, P. A. linguagem no brincar: repercussões do "faz-de-conta" para o processo de letramento. In: LODI, A. C. B.; HARRISON, K. M. P.; CAMPOS, S. R. L. Leitura e escrita no contexto da diversidade. Porto Alegre: Editora mediação, 2004.

GUARINELLO, A. C. O papel do outro na escrita de sujeitos surdos. São Paulo: Plexus, 2007.

KARNOPP, L. B. O poder da escrita e a escrita do poder. In: Lodi, A. C. Leitura e escrita no contexto da diversidade. Porto Alegre: Mediação, 2004.

KOCH, I. G. V. Desvendando os segredos do texto. 5 ed. São Paulo: Cortez, 2002.

. A coesão textual. 20 ed. São Paulo: Contexto, 2005.

ELLIAS, V. M. Ler e compreender: os sentidos dos textos. 2 ed. São Palo: Contexto, 2008. As tramas do texto. 2 ed. São Paulo: Contexto, 2014.

LODI, A. C. B.; BORTOLOTTI, E. C.; CAVALMORETTI, M. J. Z. Letramentos de surdos: práticas sociais de linguagem entre duas línguas/culturas. Bakhtiniana, v. 9, n. 2, p. 131-149, 2014.

MEIRELLES, V.; SPINILLO, A. G. Uma análise da coesão textual e da estrutura narrativa em textos escritos por adolescentes surdos. Estudos de Psicologia, v. 9, n. 1, 2004, p. 131-144.

OLIVEIRA, L. M. Prática social da escrita: um estudo de caso envolvendo a educação de adultos. Viçosa, 2013. Dissertação (Mestrado Letras) - Universidade Federal de Viçosa.

PEREIRA, M. C. C. Maria Cristina da Cunha Pereira fala sobre o ensino da Língua Portuguesa para surdos. Nova escola: 01 de dezembro de 2010. Entrevista concedida a Paula Takada. Disponível em: http://bit. ly/3aosblj. Acesso em: 21 ago 2019.

Reflexões sobre a escrita de alunos surdos expostos à abordagem bilíngue de educação. Desafios para uma nova escola: um olhar sobre o processo ensino-aprendizagem de surdos. João Pessoa: Editora da UFPB, 2011, p. 49-64.

QUADROS, R. M.; KARNOPP, L. B. Língua de sinais brasileira: estudos linguísticos. Porto Alegre: Artmed, 2004.

SABANAI, N. L. A criança surda escrevendo na língua portuguesa: questões de interlíngua. Brasília, 2008. Dissertação (Mestrado Letras) - Universidade Federal de Brasília. 
SALLES, H. M. M. L. Ensino de língua portuguesa para surdos: caminhos para a prática pedagógica. Brasília: MEC, SEESP, 2004.

SANTOS, F. M. A. Marcas da Libras e indícios de uma interlíngua na escrita de surdos em língua portuguesa. Salvador, 2009. Dissertação (Mestrado em Letras) - Universidade Federal da Bahia.

SIGNORINI, I. Apresentação. In: SIGNORINI, I. (Org.). Investigando a relação oral/escrito e as teorias do letramento. Campinas: Mercado das Letras, 2001, p. 7-19.

SILVA, A. S. Linguagem e surdez: a coesão em textos de surdos. São Paulo, 2013. Dissertação (Mestrado Letras) - Pontifícia Universidade Católica de São Paulo.

SILVA, A. A. Linguística textual e ensino: coesão e coerência na alfabetização. Claraboia, 2018, 10: 95-118. STREIECHEN, E. M.; KRAUSE-LEMKE, C. Análise da produção escrita de surdos alfabetizados com proposta bilíngue: implicações para a prática pedagógica. Revista Brasileira de Linguística Aplicada, Belo Horizonte, v. 14, n. 4, 2014, p. 957-986.

STUMPF, M. R. Aprendizagem de Escrita de Língua de Sinais pelo Sistema Signwriting: Línguas de Sinais no papel e no computador. Porto Alegre, 2005. Tese (Doutorado Educação) - Universidade Federal do Rio Grande do Sul. Faculdade de Educação. Programa de Pós-graduação em Informática na Educação.

VALADÃO, M. N.; JACINTO, C. A. Teaching and Learning Portuguese as a Second Language for Deaf Students: Reflections on Teaching Practices in An Inclusive Context. European Journal of Social Sciences Education and Research, v. 11, n. 2, 2017, p. 301-307. 